Research Paper

\title{
Phenylurenyl benzamide Analogues as a New Anti-malarial Chemotype that Potently Kill Chloroquine Resistant Parasite
}

K C RAVINDRA ${ }^{\# 1}$, DHANESWAR PRUSTY"\#2, B RUTHROTHA SELVI ${ }^{1}$, DEEPTHI SUDARSHAN ${ }^{1}$, SUMAN K DHAR ${ }^{2 *}$ and TAPAS K KUNDU ${ }^{1 *}$

${ }^{1}$ Transcription and Disease Laboratory, Molecular Biology and Genetics Unit, Jawaharlal Nehru Centre for Advanced Scientific Research, Jakkur, Bangalore 560 064, India

${ }^{2}$ Special Centre for Molecular Medicine, Jawaharlal Nehru University, New Delhi 110 067, India

(Received on 07 September 2015; Revised on 14 January 2016; Accepted on 28 January 2016)

\begin{abstract}
The growing resistance against current anti-malarial drugs represents a major health challenge, thus necessitating the development of new chemotypes targeting the malaria parasite at different stages of development. We have synthesized different phenylurenyl benzamide analogues, by the reaction of anthranilamide with different phenyl isocyanate/ isothiocyanates in a single step. These compounds in the initial in vitro assay show significant inhibitory activity over the growth of Plasmodium falciparum. Two of the derivatives, RTK41 and 43 were more potent inhibitors compared to others. The potent compounds were tested in vitro on a chloroquine-resistant strain of $P$. falciparum, which also showed significant growth inhibition. These compounds are found to be non-toxic to the mammalian cells. These results suggest that phenylurenyl bezamide analogues are a promising class of potent anti-malarial chemotypes.
\end{abstract}

Graphical Abstract:

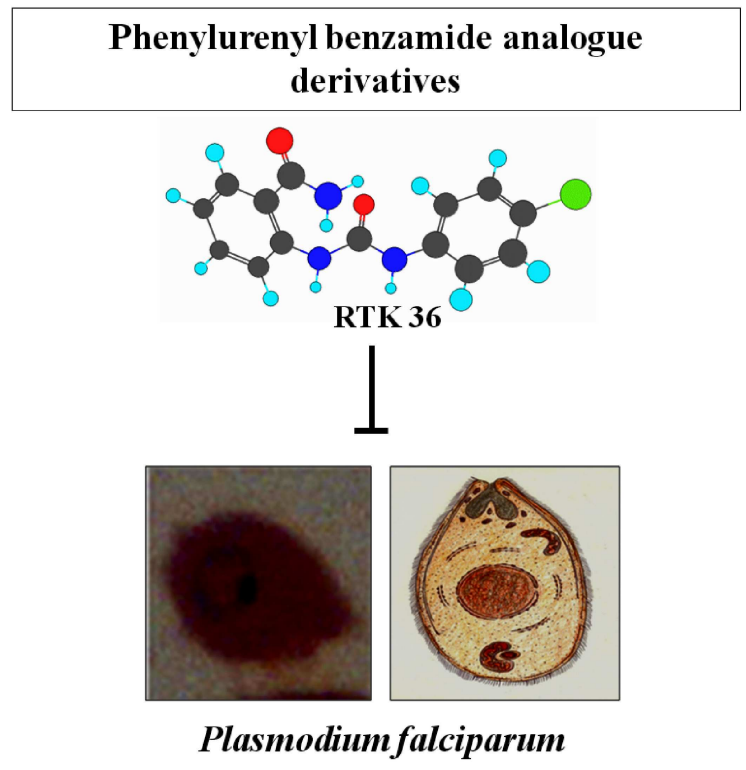

Keywords: Anti-malarial; Phenylurenyl benzamide; Plasmodium falciparum

\section{Introduction}

Malaria, one of the major re-emerging parasitic diseases, is caused by protozoal parasites belonging to the genus plasmodia. Its effect has been observed more in the third world countries, with a reported estimate of upto 214 million cases and 438,000 deaths globally in 2015 (WHO

*Author for Correspondence: E-mail: tapas@jncasr.ac.in, skdhar2002@yahoo.co.in

\#These authors contributed equally 
Report, 2015). Plasmodium falciparum is the most dreaded of the five known malaria causative Plasmodium spp. Many effective drugs such as chloroquine and sulfadoxine-pyrimethamine had been in use to treat malaria, but widespread resistance towards these drugs has limited their use in recent years. This has led to the active search for other antimalarial drugs. The naturally occurring artemisinin was identified as a potent inhibitory agent and after development as a drug it has reduced malarial mortality rates to a great extent. Unfortunately, artemisinin resistance has been confirmed to be widespread in 5 countries, including; Cambodia, the Lao People's Democratic Republic, Myanmar, Thailand and Vietnam, and is predicted to spread (WHO Report, 2015). ACTs (Artemisinin Combination Therapies) includes the combination of Artemisinin derivatives (dihydroartemisinin, artesunate and artemether) with drugs from other classes, such as;lumefantrine, mefloquine, amodiaquine, sulfadoxine/pyrimethamine, piperaquine and chlorproguanil/dapsone. ACTs are the first line of treatment for Malaria, currently, with Artemisinin mono-treatment being phased out to prevent further resistance (WHO Report, 2015). Recent studies have focused on identifying the mechanism of this drug resistance. In one lead, mutation in the Kelch 13 (K13) propeller domain was identified as a biomarker to monitor the spread of Artemisinin resistance (Ariey et al., 2014). Reduced clinical responses to the artemisinin combination drugs has once again led to an acceleration in the effort towards identifying potent inhibitors of the parasite growth (Andriantsoanirina et al., 2009; Carrara et al., 2009; Dondorp et al., 2009) .

The need to discover and develop new antimalarial therapeutics is overwhelming. The search for novel anti-malarial drugs against specific parasitic targets is thus a very important priority. The increasing burden caused by drug-resistant parasites has inspired investigators to hunt for novel anti-malarial inhibitors and drug targets, and to define the genetic basis of resistance to existing drugs, as a means to facilitate detection and develop novel strategies to overcome resistance. Anti-malarial drug development is based on several strategies, ranging from minor modifications of existing agents to the design of novel agents that act against new targets. Increasingly, available agents are being combined to improve anti- malarial regimens. Drug efficacy, pharmacology and toxicity are important parameters in the selection of compounds for the development of new anti-malarial chemotypes.

A few years ago, extensive high throughput analysis of several chemical compounds led to the identification of more than a thousand lead molecules with potential anti-malarial activity (Gamo et al., 2010). Since then, lead compounds from novel chemical scaffolds have been discovered.

Many existing anti-malarials target metabolic processes in Plasmodium, other novel targets have emerged, these include the pathways that control parasite invasion into host cells (Tham et al., 2015), host immune modulators (Jortzik et al., 2015), $\mathrm{Na}(+)$ homeostasis in the parasite (Vaidya et al., 2014), mitochondrial physiology (Chalapareddy et al., 2014), HDACs (Trenholme et al., 2014), lipid kinases PI(4)K (McNamara et al., 2013). To eradicate malaria, it is essential to find drugs against different stages of the parasitic life cycle, several drug molecules are being studied against the sexual stage of the parasite, which is responsible for malarial transmission (Maron et al., 2015; Le Manach et al., 2015; Almela et al., 2015; Trenholme et al., 2014; Eastman et al., 2013), of interest also are dual inhibitors that can target the liver stage as well as the blood stage of Plasmodium (Raphemot et al., 2015).

Some important compounds that have entered Phase II clinical trials are 1) KAE609 (Cipargamin); a spiroindolone derivative, which targets PfATP4, found through phenotypic screening, (Rottmann et al., 2010; Yeung et al., 2010) 2) KAF156; a imidazolopiperazine chemopreventative agent that is an inhibitor of the cyclic amine resistance locus (Kuhen et al., 2014) and 3) DSM265, a triazolopyrimidine-based compound is an inhibitor of dihydroorotate dehydrogenase which was discovered by high throughput screening (Coteron et al., 2011). The other class of compounds that are in clinical trials are the derivatives or synthetic versions of known malarial chemotherapy scaffolds. OZ277 (arterolane) (Valecha et al., 2010) and OZ439 (artefenomel) (Phyo et al., 2016) are synthetic endoperoxides (related to Artemisisnin derivatives) which are in Phase II clinical trials, 4-aminoquinoline derivatives such as Ferroquine (Supan et al., 2012) and AQ13 (Mzayek et al., 2007) 
are also in Phase II clinical trials. Thus, increasing the diversity of anti-malarial therapeutics is of utmost importance to overcome the high rate of resistance development in malaria causing Plasmodium falciparum. Incidentally, the WHO has issued a second Global Malaria Action Plan, named "Action and investment to defeat malaria 2016-2030 (AIM) for a malaria-free world", to contain malaria by 2030. It is thus evident that novel scaffolds for anti-malarial treatments will be extremely timely.

There are several chemotypes identified with potential anti-malarial activity based on experimental designing as well as chemical genetic screen approaches. Although, the amide linkage and the scaffold of urea (Domínguez et al., 2005; Gamo et al., 2010; Guiguemde et al., 2010; Trager and Jensen, 1976) has been hypothesized, the combination of these two functional entities have not yet been attempted. In the present study, a novel chemotype-phenylurenyl benzamide containing urea scaffold with amide linkage has been synthesized, derivitized and tested for its anti-malarial activity. Fourteen derivatives of phenylurenyl benzamide were synthesized, out of which two derivatives, show potent in vitro antiplasmodial activity against chloroquine sensitive and chloroquine resistant $P$. falciparum strains. Parasitemia and stage-specific development were assessed in different time points of the intraerythrocytic life cycle and compared with drug free control. The normal development of parasites till schizont stage during the course of the drug treatment indicates a possible role of these derivatives in the invasion process of new host cells. However, in-depth studies of these drugs may also provide clues of their mechanism of action that may further offer scope for improvement of their anti-malarial activity.

\section{Materials and Methods}

\section{General Procedure for the Synthesis of Phenylurenyl benzamide Analogues}

The mixture of anthranilamide and corresponding phenyl isocyanate/isothiocyante was dissolved in dry diethyl ether (1:1 equivalence) (Beaver et al., 1957) $(50 \mathrm{ml})$. The reaction mixture was stirred at room temperature in presence of nitrogen as per the indicated time of reaction. The resulting solid was filtered and purified by column chromatography. ${ }^{1} \mathrm{H}$ nuclear magnetic resonance (NMR) spectra were recorded at $400 \mathrm{MHz}$ on a Bruker AC 400 spectrometer; chemical shifts are reported in (ppm) units relative to the internal reference tetramethylsilane $\left(\mathrm{Me}_{4} \mathrm{Si}\right)$. All compounds were routinely checked by thin-layer chromatography (TLC) and ${ }^{1} \mathrm{H}$ NMR. High-resolution mass spectrometry was obtained on a Bruker Daltonics APEX II (for electrospray ionization). TLC was performed on aluminum-backed silica gel plates (Merck DCAlufolien Kieselgel 60 F254) with spots visualized by UV light. All solvents were reagent grade and when necessary, were purified and dried by standard methods. Concentration of solutions after reactions and extractions involved the use of a rotary evaporator operating at a reduced pressure. Organic solutions were dried over anhydrous sodium sulfate. Analytical results are within $\pm 0.50 \%$ of the theoretical values. All chemicals were purchased from SigmaAldrich and were of the highest purity. The crystal structure of RTK 36 was solved by Bruker X8 APEX instrument.

\section{Parasite Culture}

Plasmodium falciparum chloroquine sensitive strain 3D7 and chloroquine resistant strain W2 were cultured continuously in human $\mathrm{O}+$ red blood cell in RPMI 1640 (Invitrogen) medium supplemented with $0.5 \%$ Albumax (Invitrogen), 0.2\% $\mathrm{NaHCO}_{3}, 27.2 \mathrm{mg} / \mathrm{lt}$ Hypoxanthine and Gentamycin sulphate $(10 \mu \mathrm{g} / \mathrm{ml})$. For the synchronization of parasites, cells were treated with 5\% sorbitol, every $48 \mathrm{hrs}$. The protocol used for parasite culture is a modified form of standard protocol described elsewhere (Trager and Jensen, 1976).

In vitro assay for inhibition of $P$. falciparum erythrocytic growth and development in the presence of RTK drugs.

The compounds were dissolved in DMSO to get a $10 \mathrm{mM}$ stock solution. Synchronized $P$. falciparum parasites at ring stage (between 14-18hrs) were challenged with different concentration of test compounds in triplicate. Subsequently, parasites were incubated in 12 -well tissue culture plate at $37^{\circ} \mathrm{C}$. Thin blood smear slides were made at different time points of intra-erythrocytic life cycle. The Giemsa stained slides were examined for counting the number of parasites in random adjacent microscopic fields. 
Percentage of infection (parasitemia) was calculated from 500 RBCs from each slide. Finally, the average percentages of the triplicate culture with standard deviation were plotted against different drug concentration. Giemsa stained slides were also used to study parasite morphology.

\section{Mammalian Cell Culture}

HeLa cells were maintained at $37^{\circ} \mathrm{C}$ in Dulbecco's modified Eagle medium (DMEM) supplemented with $10 \%$ fetal bovine serum (Hyclone) and appropriate antibiotics in $5 \% \mathrm{CO}_{2}$ incubator.

\section{MTT Cytotoxicity Assay}

Mammalian cells ( 5000 cells) were seeded in 96 well plate. The cells were treated with the inhibitor for 24 and $48 \mathrm{hrs}$. 5 hours prior to completion of the incubation, $20 \mu \mathrm{l} \mathrm{MTT} \mathrm{(} 5 \mathrm{mg} / \mathrm{ml}$ stock) was added to the culture media and incubated at $37^{\circ} \mathrm{C}$ for $5 \mathrm{hrs}$. The media was aspirated with the help of a needle and $200 \mu \mathrm{l}$ of DMSO was added to solubilize the crystals. After mixing by pipetting, the cells were incubated at $37^{\circ} \mathrm{C}$ for 5 mins and the absorbance was recorded at $540 \mathrm{~nm}$ in an ELISA reader (VERSA
Max microplate reader, Molecular Devices). The values were normalized with the untreated control and plotted. Error bars in figures indicate the standard deviation.

\section{Results}

This work was initiated towards the development of newer scaffolds which could have anti-malarial activity. In accordance with this, several phenylurenyl benzamide analogues were synthesized. The reaction of phenyl isocyanate/isothiocyanates with amine, forming a urea or thiourea, is very fast and does not require any catalyst. The anthranilamide on reaction with phenyl isocyanate/isothiocyanates in diethyl ether at room temperature, gives a stable urea compound in almost analytically pure forms which is highly stable. The most interesting feature of this synthesis is that, we achieved these target molecules in a single step with a greater yield. The 2-\{[(4-chlorophenyl) carbamoyl]amino \}benzamide derivative; RTK36 which was crystallized (Figs. 1A and B) and confirmed for its purity, was tested on P. falciparum for assaying its inhibitory potential.

A

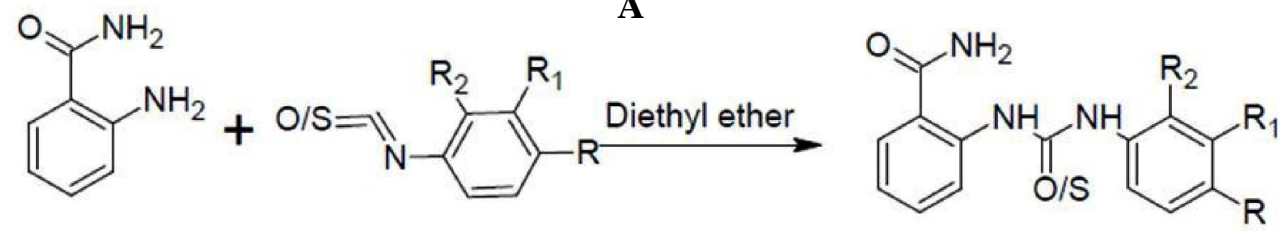

B

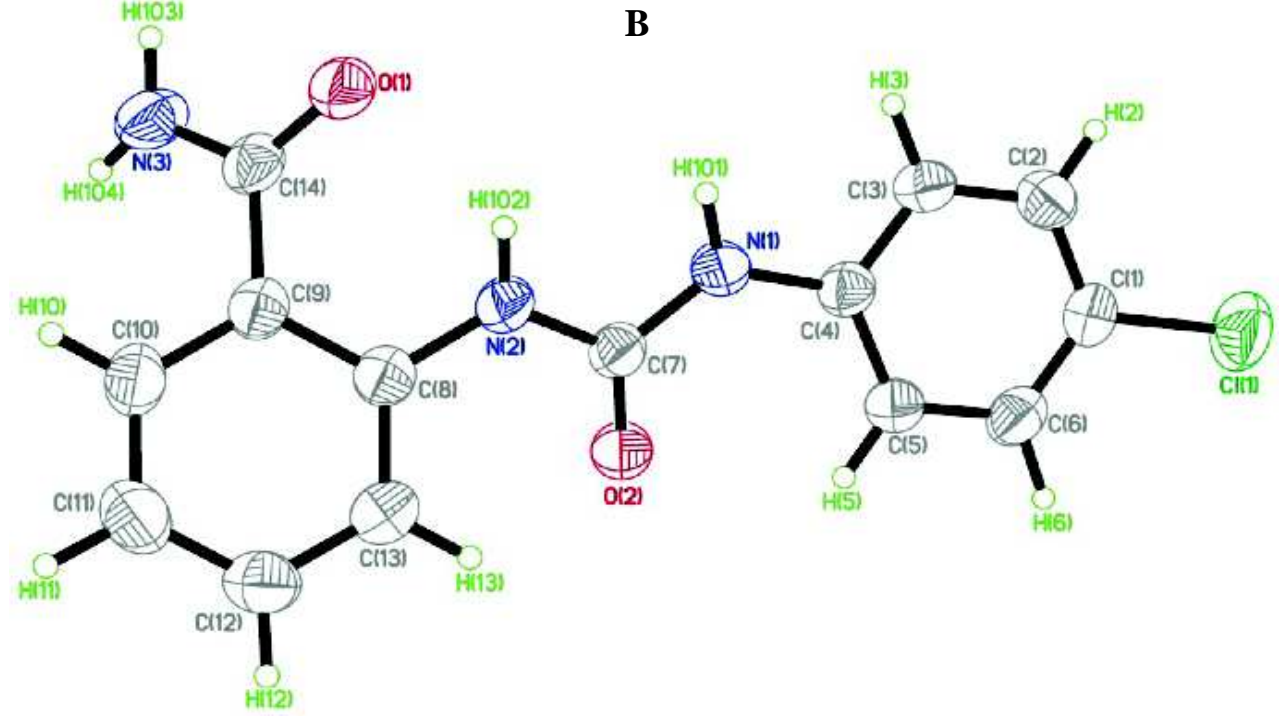

Fig. 1: (A) The reaction of anthralamide with different phenyl isocyanate/isothiocyanate in 1:1 equivalence resulted in corresponding phenylurenyl benzamides in a single step. (B) The crystal structure of RTK 36 solved by Bruker 180 
The anti-malarial activity of RTK36 was quantified on chloroquine (CQ)-susceptible $P$. falciparum strain 3D7. Highly synchronous parasites 14-18 hrs post invasion were challenged with RTK36 over a high concentration range of $50 \mu \mathrm{M}$ to $100 \mu \mathrm{M}$ and parasite growth was assayed at 58 and $92 \mathrm{hrs}$ post invasion. Ciprofloxacin, a known, gyrase inhibitor that kills the parasites at the second life cycle (Goodman et al., 2007) was taken as the positive control. Of the six different concentrations of RTK36 tested, RTK36 at $60 \mu \mathrm{M}$ and above was found to be highly effective in both the life cycles (Fig. 2A, lanes 2 versus 3-8). DMSO control had no significant effect on parasite growth (Figs. 2A, lane 2). Ciprofloxacin exhibited potent inhibitory potential on the parasite growth at $10 \mu \mathrm{M}$ concentration (Fig. 2A, lane 9). To characterize the cellular effect of the drug, we observed the giemsa stained smears of the drug treated culture from different intra-erythrocyte stages of life cycle. Under RTK36 treatment, progression through the first life cycle was indistinguishable from that seen in untreated cells (Fig. 2B and C, DMSO versus treated lanes). In the second life cycle, the growth of the parasites treated with $60 \mu \mathrm{M}$ and above of RTK 36 was found to be slower in comparison to untreated parasites. The decrease in parasitemia without affecting the growth in the first life cycle suggests the incapability of parasites to invade the new host cells in the presence of RTK36.

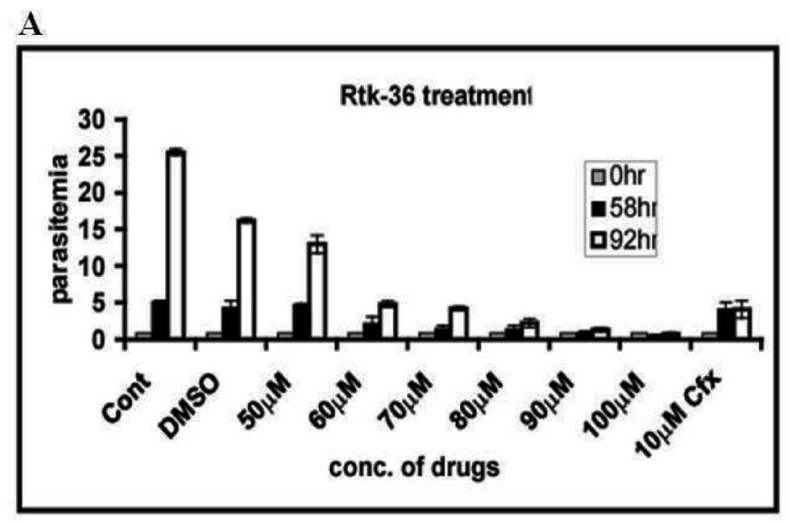

B
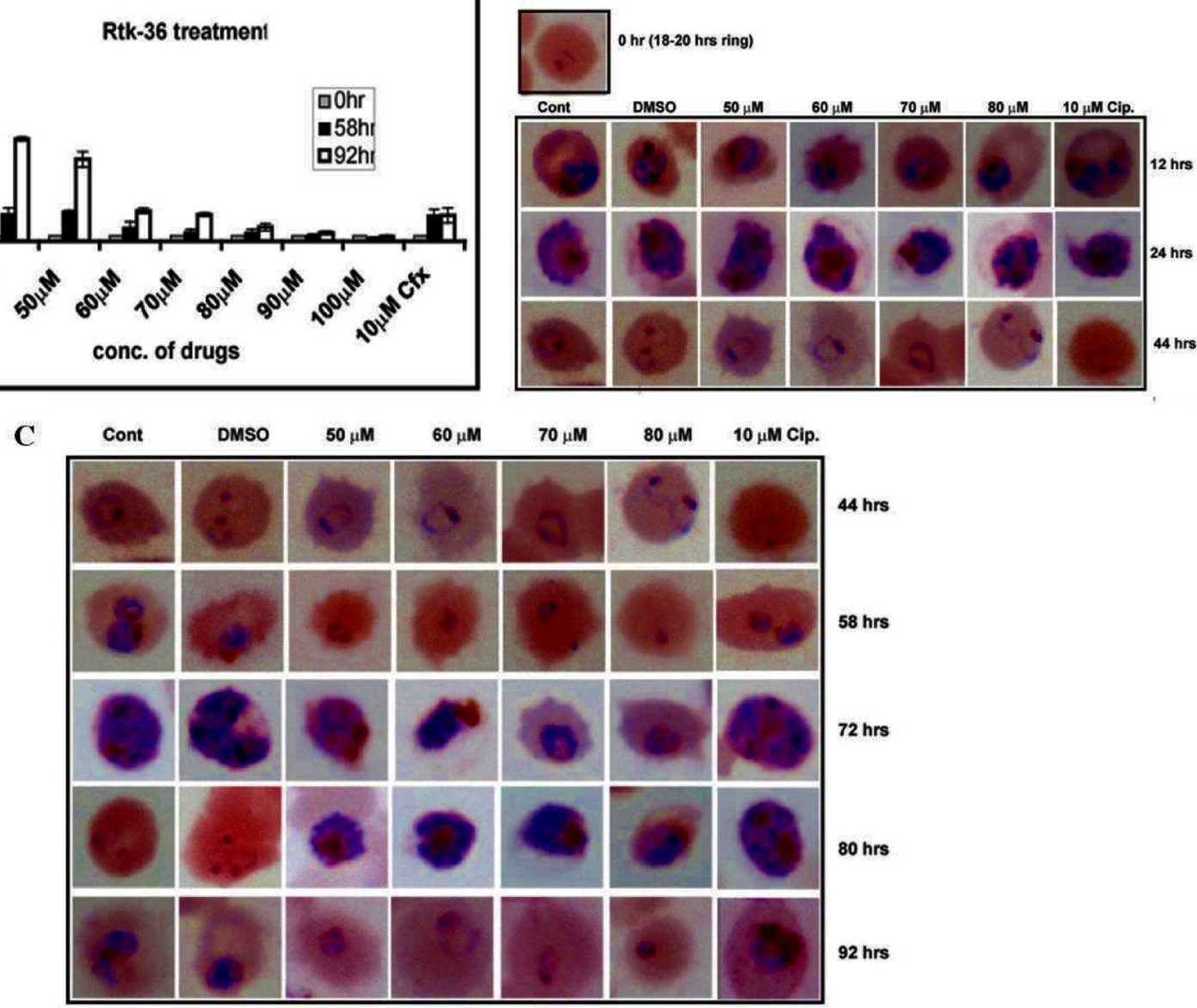

Fig. 2: (A) Effect of RTK 36 on in vitro growth of $P$. falciparum at different concentrations. Parasitemia estimated by microscopic observation of Giemsa stained smears at 0,58 and 92 hours following treatment with different concentration of RTK 36

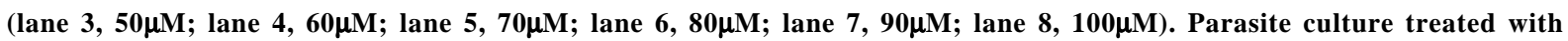
(lane 2) and without DMSO (lane 1) served as controls. Parasite cultured with $10 \mu M$ ciprofloxacin (lane 9) was used as positive control. (B) Parasite morphology at 12, 24 and 44 hrs at indicated concentration of RTK 36 in the first life cycle. In the first life cycle the compound does not have any significant effect on the parasite morphology. (C) Parasite morphology at different time points at indicated concentration of RTK 36 in the second life cycle. In the second life cycle, the effect of RTK 36 is seen clearly in a dose dependent manner 
Table 1: Structures of Phenylurenyl benzamide analogues with different functional groups or hetero atoms at the phenyl ring

\begin{tabular}{|c|c|c|c|c|c|c|c|}
\hline Comp. name & Structure of the molecule & Reaction time & Yield & Comp. name & Structure of the molecule & Reaction time & Yield \\
\hline RTK36 & & $50 \mathrm{~min}$. & $95 \%$ & RTK44 & & $1 \mathrm{hr}$ & $95 \%$ \\
\hline RTK37 & & 23 hrs & $90 \%$ & RTK45 & & 4 hrs & $94 \%$ \\
\hline RTK38 & & $2 \mathrm{hrs}$ & $90 \%$ & RTK46 & & $5 \mathrm{~min}$. & $86 \%$ \\
\hline RTK39 & & $3 \mathrm{hrs}$ & $86 \%$ & RTK47 & & $3 \mathrm{hrs}$ & $91 \%$ \\
\hline RTK41 & & $6 \mathrm{hrs}$ & $88 \%$ & RTK4S & & 3 hrs & $89 \%$ \\
\hline RTK42 & & $4 \mathrm{hrs}$ & $88 \%$ & RTK49 & & $16 \mathrm{hrs}$ & $81 \%$ \\
\hline RTK43 & & $40 \mathrm{~min}$. & $93 \%$ & RTK50 & & $1 \mathrm{hr}$ & $94 \%$ \\
\hline
\end{tabular}

There was a $60 \%$ decline in parasitemia during first life cycle when the parasites were treated with RTK36 $(70 \mu \mathrm{M})$. Subsequently, the antimalarial activities of different derivatives of RTK36, represented in Table 1 were tested at a concentration of $70 \mu \mathrm{M}$. RTK41 and RTK43 were found to be the most effective among all the substitutes (Figs. 3A, lanes 2 versus lane 7 and lane 9). Further characterization of the inhibitory potential of these two drugs was done at lower concentrations ranging from $15 \mu \mathrm{M}$ to $70 \mu \mathrm{M}$. The thiol analogue of RTK36, RTK41 showed an $\mathrm{IC}_{50}$ value similar to the parent compound ( $\sim 65 \mu \mathrm{M})$ (Fig. 3B). Interestingly, RTK43 (bromo-substituent) showed a better inhibitory potential on $P$. falciparum growth with an $\mathrm{IC}_{50}$ value close to $\sim 30 \mu \mathrm{M}$ (Fig. 3C).
Chloroquine resistance has become a major challenge in the field of malarial chemotherapy worldwide (Wellems, 2002). Hence, the anti-plasmodial activity of the most effective derivatives was tested on the chloroquine resistant $P$. falciparum strain, W2. The efficacy of RTK41 and RTK43 were tested on the W2 strain at concentrations that showed inhibitory effect on the chloroquine sensitive P. falciparum 3D7 strain growth. Significantly, both the derivatives were found to inhibit the growth of the W2 strain. RTK43 was more effective at lower concentration than RTK41 ( 30 $\mu \mathrm{M})$, (Fig. 4A and 4B, lane 2 versus 3$5)$. These datasets indicate promising prospects for the phenylurenyl benzamide analogues RTK41 and RTK43 as antimalarial chemotypes, which possess potent anti-plasmodial activity even on the chloroquine resistant strain. Although the untreated parasite culture 

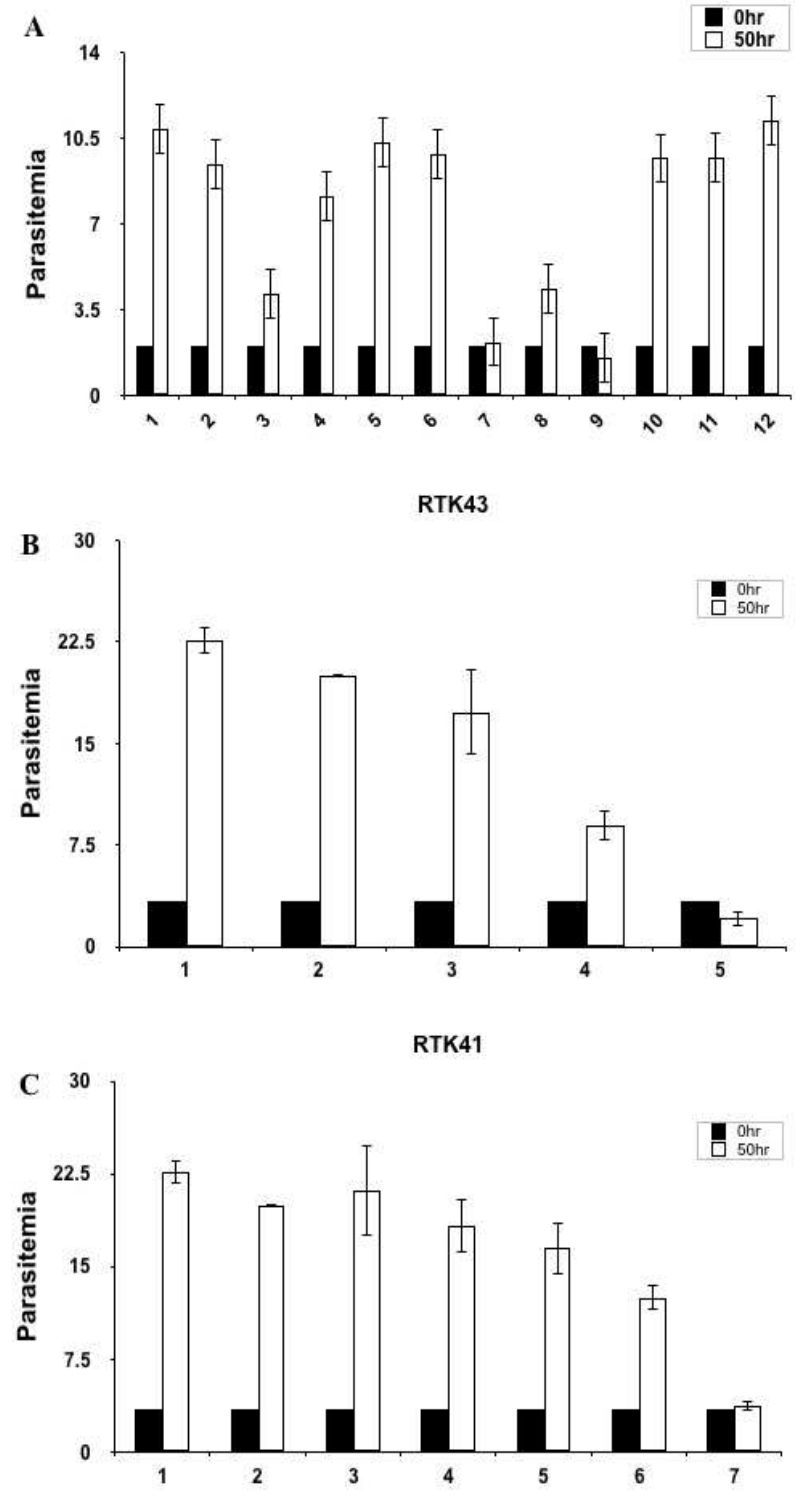

Fig. 3: (A) Effect of different RTK analogues (lane 3, RTK36; lane 4, RTK37; lane 5, RTK38; lane 6, RTK39; lane 7, RTK41; lane 8, RTK42; lane 9, RTK43; lane 10, RTK44; lane 11, RTK45; lane 12, RTK46) on in vitro growth of $P$. falciparum at $70 \mu \mathrm{M}$ concentration. Of the ten different analogs tested, RTK 41 and RTK 43 emerged as potent anti-malarials. Lane 1 is the untreated control whereas lane 2 represents the DMSO control. (B) In vitro anti-Plasmodial activity RTK 43 at different concentrations (lane $3,15 \mu \mathrm{M}$; lane $4,30 \mu \mathrm{M}$; lane 5, $45 \mu \mathrm{M})$. Lane 1 and Lane 2 represent the untreated and DMSO treated controls. RTK 43 is effective at $30 \mu \mathrm{M}$ concentration. (C) In vitro anti-Plasmodial assay of RTK 41 at different concentrations (lane 3, $15 \mu \mathrm{M}$; lane $4,30 \mu \mathrm{M}$; lane $5,45 \mu \mathrm{M}$; Lane $6,60 \mu \mathrm{M}$; Lane $7,70 \mu \mathrm{M})$. Lane 1 and Lane 2 represent the untreated and DMSO treated controls. At $70 \mu \mathrm{M}$ concentration, RTK 41 kills the parasites more effectively.
A

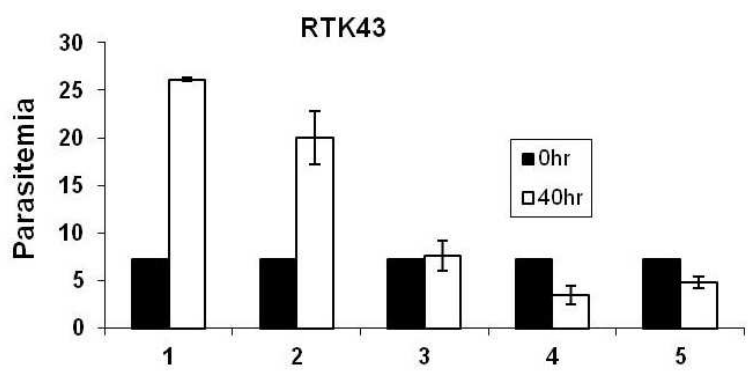

B

RTK41

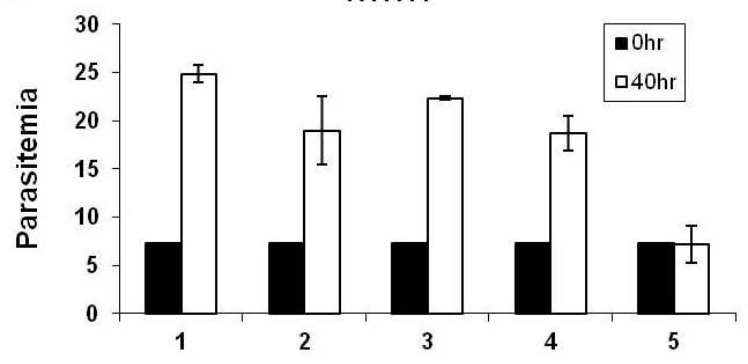

Fig. 4: Effect of RTK 43 (A) and RTK41 (B) on in vitro growth of Chloroquine resistant W2 strain of $P$. falciparum. Lane 1 and 2 represent the untreated and DMSO treated controls. Lane 3-5 $(30 \mu \mathrm{M}, 45 \mu \mathrm{M}, 60 \mu \mathrm{M}$ resp.) Parasitemia in the control culture increased to $25 \%$ from initial $5 \%$ (lane 1), while parasitemia in the drug treated culture (lane 3-5) decreased in a dose dependent manner

showed a five-fold increase in the parasitemia, the compound treated culture exhibited an arrest as no increase in parasitemia was observed (Figs. 4A and 4B, lane 1 versus lane 5).

Since, the compounds tested produced encouraging results with the chloroquine resistant strain, the effect of the derivatives were also tested on mammalian cells to check for any apparent cytotoxicity on other cell types. Interestingly, none of the compounds tested at the concentration that kills parasites, exhibited any toxic effects on the mammalian cells, HeLa for 24 hrs (Fig. 5A) and 48 hours (Fig. 5B). However, the derivatives RTK41 and RTK43 showed mild cytotoxic effects at $100 \mu \mathrm{M}$ concentration at $24 \mathrm{hrs}$ which also showed a timedependence as tested by MTT assay (Fig. 5A and $5 \mathrm{~B}$, compare lane 2 versus 3-8). By $48 \mathrm{hrs}$, the bromo analogue also led to a $50 \%$ reduction in the mammalian cell viability (Fig. 5A and 5B, lane 8). However, at the similar concentrations, a known apoptosis inducing compound, Plumbagin was used as a control which showed a dose dependent cytotoxicity (Fig. 5A and 
A

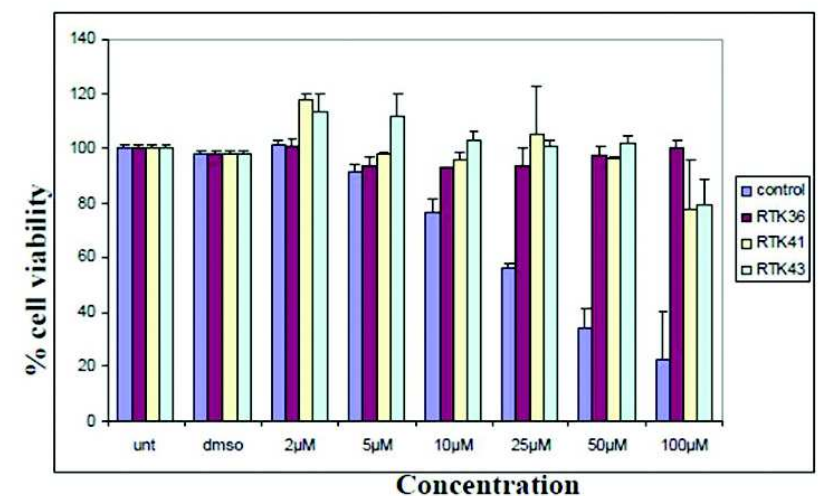

C

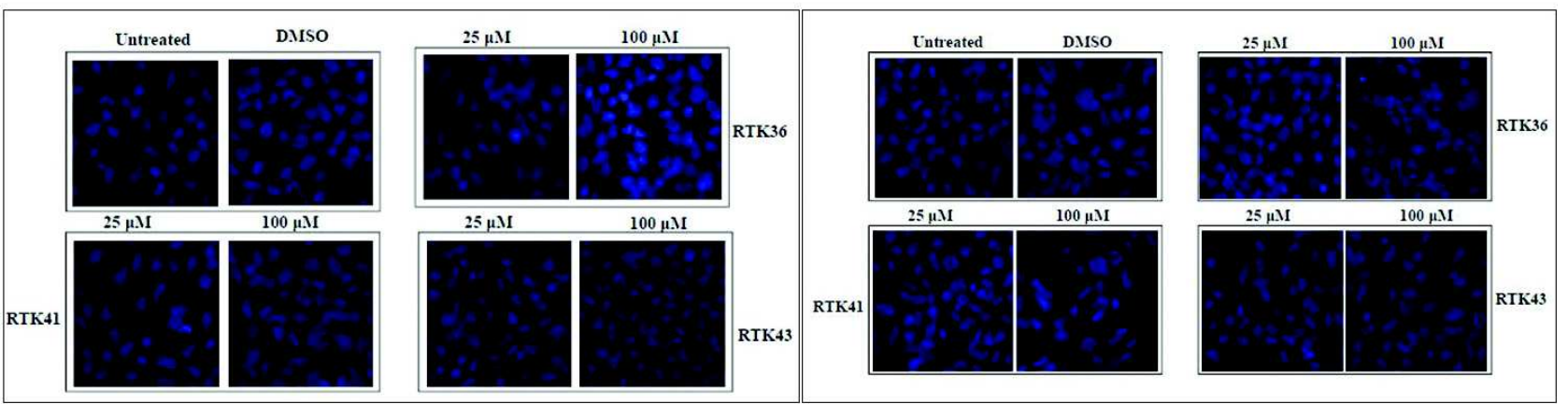

B

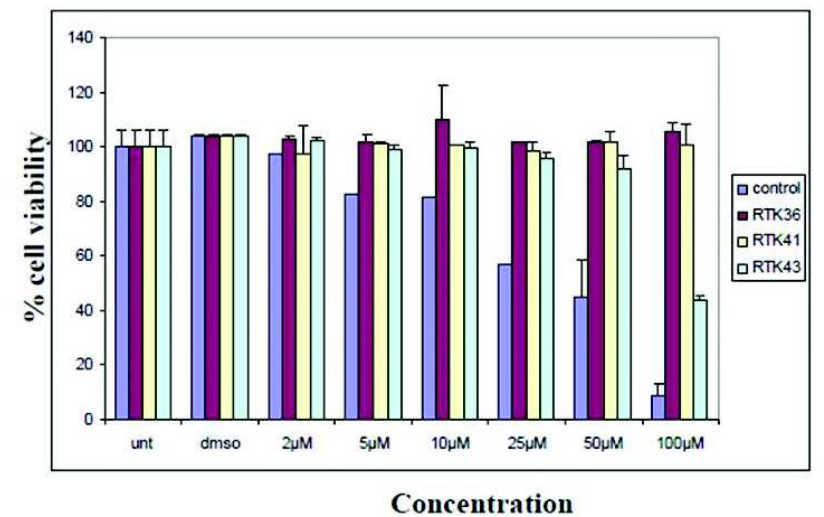

D

Fig. 5: (A and B) MTT-based cytotoxicity assay, where blue bars represent control (plumbagin) treated cells, red bars represent RTK36-treated cells, yellow bars represent RTK41-treated cells and light blue bars represent RTK43-treated cells for 24

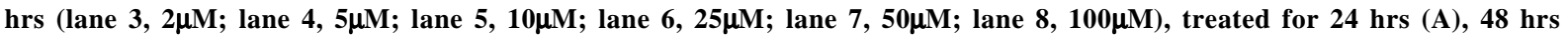
(B). (C and D) The top left panel represents the confocal image of HeLa cells with and without treatment of DMSO. Remaining panels represent the confocal image of HeLa cells on treatment with RTK 36, 41 and 43 at the concentration of 25 and $100 \mu \mathrm{M}$ for $24 \mathrm{hrs}(\mathrm{C})$ and $48 \mathrm{hrs}(\mathrm{D})$

5B, compare lane 2 versus lane 3-8, blue bar). Additionally, the cellular morphology was also tested by examining the compound treated cells by performing a Hoechst staining followed by microscopic visualization of the cell nuclei (Fig. 5C and 5D). Taken together, all these observations, suggest that the phenylurenyl benzamide analogues, RTK36, 41 and 43 are novel anti-malarial chemotypes which inhibit the growth of the malaria parasite, $P$. falciparum. The RTK36 and 41 compounds which exhibit no apparent cytotoxicity to mammalian cells also show similar anti-malarial activity, indicating their mechanism of action to be specific to the parasite. Although, the bromo analogue was found to be the most effective, it had mild cytotoxic effects.

\section{Discussion}

The existing anti-malarial drugs have been developed targeting different stages of the malarial life cycle. Most well established drug chloroquine prevents hemozoin formation (Loria et al., 1999) and several antimalarial drugs (de Villiers and Egan, 2009) have been developed targeted towards this process. Recently, a dual functioning molecule was synthesized wherein reactive nitrogen was included to enhance the accumulation of the compound in digestive vacuole by acid trapping (Kelly et al., 2009). Due to the development of chemoresistance, especially because of the evolution of the Plasmodium falciparum chloroquine resistance transporter, PfCRT (Johnson et al., 2004), other molecules were developed which could act on other essential pathways. One such example is atovaquone, that targets cytochrome $b$ and it is a complex III inhibitor (Hudson, 1993). Proguanil, which targets dihydrofolate reductase is another drug used in combination with the former two drugs 
(Rastelli et al., 2000). The most successful candidate so far has been artemisinin, a component of Chinese herbal medicine, which inhibits the parasite growth very effectively (Klayman, 1985). However, its exact mechanism of action has been controversial with reports suggesting its action on haem as well as on the digestive vacuole. Due to its short half-life, the administration of the drug has to be done more frequently. Hence, combination strategies using artemisinin were attempted. Some highly effective combinations are artemether-lumefantrine and artesunate-mefloquine (Mueller et al., 2006; Soukhathammavong et al., 2011). One such combination that proved highly effective was the artemisinin and curcumin, which exhibited high potency against the malaria infection in mice model (Nandakumar et al., 2006). Since, curcumin is a known histone acetyltransferase inhibitor (Balasubramanyam et al., 2004) this combination might have had better efficacy due to targeting respiratory as well as epigenetic processes. Recently, several reports worldwide have indicated reduced clinical responses in patients treated with artemisinin (Aurrecoechea et al., 2009); hence, there has been a spurt in the search for other chemotypes targeting the malaria parasite. Furthermore, the sequencing of the parasite genome, and several biochemical evidences now strongly support the stage specific expression of several proteins, such as kinases and transporters which play an important role in the parasite pathogenesis (Russo et al., 2010). Hence, new chemotherapeutic agents should be designed based on these temporally expressed proteins.

In this study, a series of phenylurenyl benzamide analogues are synthesized and tested for in vitro antimalarial activity. The synthesis of title compounds were achieved in a single step with a yield of $>80$ $90 \%$. The remarkable part of this synthesis is that the compounds thus obtained after the reactions were almost analytically pure forms. When we tested inhibitory activity against cultured $P$. falciparum parasites, out of fourteen compounds, only three compounds showed excellent inhibitory activity against the parasites. A striking anti-parasitic activity was exhibited by the compound RTK 43 containing urea linkage and bromo group at the para position in the phenyl ring. However, RTK 41, which has thiourea bridge and chloro group at its ortho position, was less potent than RTK43. RTK 36, which has a urea linkage and chloro moiety at para position, is less potent than RTK 41 and RTK 43. By considering the common scaffold of all three compounds, and evaluating the structure-activity relationship of these different structural analogues of phenylurenyl benzamide, it seems that the urea bridge is much more effective than thiourea linkage between amide and phenyl rings. The position of electro negative elements at the phenyl ring is very important for the activity. Interestingly, thiourea derivatives (RTK 48, 49, 50) which have electronegative elements (bromo, fluoro and chloro) at para position do not show any significance activity for example, RTK 42, which has a fluoro moiety at ortho position and RTK 37 (which does not have any electronegative element at the phenyl ring). On the other hand, the urea bridge containing compounds RTK 39 (m-methoxy), RTK 44 (p-sulphomethyl), RTK 45 (p-fluoro), RTK 46 (disubstituted, m-trifluro, pchloro), RTK 47 (p-trifluoro), did not exhibit any inhibitory activity against $P$. falciparum. One more interesting observation is that in spite of high structural similarity between RTK 36 and RTK 38 except for the position of chloro group, RTK 36 showed significant effect, whereas RTK38 did not. On comparing RTK 43 and RTK 36, both of them possess urea bridge between amide and phenyl rings, but the para position is occupied by bromo and chloro groups respectively. However, RTK 43 is more potent than RTK 36, which means that the less electro negative element (bromo) at para position may increase its potency, which plays an important role in the inhibition of parasites. Thus, the different chemical entities could help greatly in fine-tuning the inhibitory potential against the malarial parasites. It should be noted that this study is a preliminary attempt at characterising this novel scaffold, only halo-group (bromo, fluoro and chloro) modifications have been attempted here. Based on the current literature, retaining the urea linkage with further amide modifications can be attempted on this scaffold. Thus, a wide range of novel modifications are possible on this scaffold and could yield a lead molecule with efficacy in the nano molar range.

The effect of the phenylurenyl benzamide derivatives tested in this study on the parasite growth indicates its effect on the invasion process, i.e., entry into the second life cycle. Several kinases including 
plasmepsins have been recently identified to be expressed during the process of schizogony and invasion of new RBCs (Russo et al., 2010). Incidentally, the parent compound RTK36 was identified in a screen for aurora kinase inhibitors and showed excellent docking to the enzyme, away from the active site or ATP binding site (data not shown). However, the interacting residues identified in this molecular modeling were found to be conserved in other kinases such as CAMK and MAPK of humans. It has been observed that, the $P$. falciparum kinases have several homologs to the members of the above kinases (Ward et al., 2004). An initial in vitro assay using the parasite lysate on histone $\mathrm{H} 1$ substrate in the presence of RTK41 and 43, indicates a mild hyperphosphorylation of histone H1 (Fig. S1). Since, the parasite lysate is a rich source of several kinases; it is apparently difficult to detect any specific targets. However, the effect on the in vitro kinase assay suggests, a possible kinase target for the phenylurenyl benzamide analogues. Furthermore, the treatment of these drugs delays the parasite life cycle (Fig. 2), with an arrest in the late trophozoite/early schizont stage at higher concentrations. This morphology is similar to the knockout of a kinase stabilizer involved in this final stage of cell proliferation (Dvorin et al., 2010). Hence, the effect of these derivatives might be at a distinct stage of the parasite life cycle especially on kinases or kinase stabilizers.

Alternatively, in a study that performed a high throughput characterization of several chemical scaffolds, leading to the identification of many new chemotypes, a urea linkage compound with a piperidine and piperazine moiety, TCMDC 139221 was described which was hypothesized to act as a lipid amide hydrolase inhibitor (Gamo et al., 2010). Since, the central scaffold is similar to the RTK derivatives screened, it is indeed possible that these drugs could

\section{References}

Almela M J, Lozano S, Lelièvre J, Colmenarejo G, Coterón J M, Rodrigues J, Gonzalez C and Herreros E (2015) A New Set of Chemical Starting Points with Plasmodium falciparum Transmission-Blocking Potential for Antimalarial Drug Discovery PLoS One 10 e0135139

Andriantsoanirina V, Ratsimbasoa A, Bouchier C, Jahevitra M, Rabearimanana S, Radrianjafy R, Andrianaranjaka V, act on the same target. Hence, these chemotypes could be used for designing potent anti-malarial drugs, since their mode of action is at distinct stage of the parasite life cycle without any apparent cytotoxicity on the mammalian cells.

Taken together, this study establishes a new chemotype, phenylurenyl benzamide. The study has explored the possibility of different chemical functional groups to identify the most efficient anti-plasmodial agent. Preliminary results suggest the role of these compounds on specific stages of $P$. falciparum during its intra-erythrocytic development. Moreover, with technologies available today such as nano-targeting, it could be possible to improve the bioavailability of phenylurenyl benzamide derivatives, probably increasing its efficacy. Thus, this scaffold could be exploited for identifying newer targets and efficient compounds to combat malaria.

(Supporting information at the end of the paper)

\section{Acknowledgment}

We thank Department of Biotechnology, Government of India and Jawaharlal Nehru Centre for Advanced Scientific Research (JNCASR) for financial assistance. B S Suma for confocal microscopy, MBGU, X-ray crystallography facility of CPMU, JNCASR. SKD acknowledges Swarnajayanti Fellowship provided by Department of Science and Technology. DP acknowledges CSIR, India for fellowship. TKK acknowledges JC Bose Fellowship provided by the Department of Science and Technology, Govt of India. We acknowledge Rahul Sharma, Special Centre for Molecular Medicine, Jawaharlal Nehru University for providing the Plasmodium falciparum confocal image for the cover figure.

Randriantsoa T, Rason M A, Tichit M, Rabarijaona L P, Mercereau-Puijalon O, Durand R and Ménard D (2009) Plasmodium falciparum drug resistance in Madagascar: facing the spread of unusual pfdhfr and pfmdr-1 haplotypes and the decrease of dihydroartemisinin susceptibility Antimicrob Agents Chemother 53 4588-97

Ariey F, Witkowski B, Amaratunga C, Beghain J, Langlois A C, Khim N, Kim S, Duru V, Bouchier C, Ma L, Lim P, Leang 
R, Duong S, Sreng S, Suon S, Chuor C M, Bout D M, Ménard S, Rogers W O, Genton B, Fandeur T, Miotto O, Ringwald P, Le Bras J, Berry A, Barale J C, Fairhurst R M, Benoit-Vical F, Mercereau-Puijalon O and Ménard D (2014) A molecular marker of artemisinin-resistant Plasmodium falciparum malaria Nature 505 50-55

Aurrecoechea C, Brestelli J, Brunk B P, Dommer J, Fischer S, Gajria B, Gao X, Gingle A, Grant G, Harb O S, Heiges M, Innamorato F, Iodice J, Kissinger J C, Kraemer E, Li W, Miller J A, Nayak V, Pennington C, Pinney D F, Roos D S, Ross C, Stoeckert C J, Treatman C and Wang H (2009) PlasmoDB: a functional genomic database for malaria parasites Nucleic Acids Res 37 (Database issue) D539-43

Balasubramanyam K, Altaf M, Varier R A, Swaminathan V, Ravindran A, Sadhale P P and Kundu T K (2004) Polyisoprenylated benzophenone, garcinol, a natural histone acetyltransferase inhibitor, represses chromatin transcription and alters global gene expression $\mathrm{J}$ Biol Chem 279 33716-26

Beaver D J, Roman D P and Stoffel P J (1957) The Preparation and Bacteriostatic Activity of Substituted Ureas $J \mathrm{Am}$ Chem Soc 79 1236-1245

Carrara V I, Zwang J, Ashley E A, Price R N, Stepniewska K, Barends M, Brockman A, Anderson T, McGready R, Phaiphun L, Proux S, van Vugt M, Hutagalung R, Lwin K M, Phyo A P, Preechapornkul P, Imwong M, Pukrittayakamee S, Singhasivanon P, White N J and Nosten $\mathrm{F}$ (2009) Changes in the treatment responses to artesunatemefloquine on the northwestern border of Thailand during 13 years of continuous deployment PLoS One 4 e 4551

Chalapareddy S, Bhattacharyya M K, Mishra S and Bhattacharyya S (2014) Radicicol confers mid-schizont arrest by inhibiting mitochondrial replication in Plasmodium falciparum Antimicrob Agents Chemother 58 4341-52

Coteron J M, Marco M, Esquivias J, Deng X, White K L, White J, Koltun M, El Mazouni F, Kokkonda S, Katneni K, Bhamidipati R, Shackleford D M, Angulo-Barturen I, Ferrer S B, Jiménez-Díaz M B, Gamo F J, Goldsmith E J, Charman W N, Bathurst I, Floyd D, Matthews D, Burrows J N, Rathod P K, Charman S A and Phillips M A (2011) Structure-guided lead optimization of triazolopyrimidinering substituents identifies potent Plasmodium falciparum dihydroorotate dehydrogenase inhibitors with clinical candidate potential J Med Chem 54 5540-61

de Villiers K A and Egan T J (2009) Recent advances in the discovery of haem-targeting drugs for malaria and schistosomiasis Molecules 14 2868-87
Domínguez J N, León C, Rodrigues J, Gamboa de Domínguez N, Gut J and Rosenthal P J (2005) Synthesis and evaluation of new antimalarial phenylurenyl chalcone derivatives $J$ Med Chem 48 3654-8

Dondorp A M, Nosten F, Yi P, Das D, Phyo A P, Tarning J, Lwin K M, Ariey F, Hanpithakpong W, Lee S J, Ringwald P, Silamut K, Imwong M, Chotivanich K, Lim P, Herdman T, An S S, Yeung S, Singhasivanon P, Day N P, Lindegardh N, Socheat D and White N J (2009) Artemisinin resistance in Plasmodium falciparum malaria N Engl J Med 361 455-67

Dvorin J D, Martyn D C, Patel S D, Grimley J S, Collins C R, Hopp C S, Bright A T, Westenberger S, Winzeler E, Blackman M J, Baker D A, Wandless T J and Duraisingh M T (2010) A plant-like kinase in Plasmodium falciparum regulates parasite egress from erythrocytes Science $\mathbf{3 2 8}$ 910-2

Eastman R T, Pattaradilokrat S, Raj D K, Dixit S, Deng B, Miura K, Yuan J, Tanaka T Q, Johnson R L, Jiang H, Huang R, Williamson K C, Lambert L E, Long C, Austin C P, Wu Y and Su XZ (2013)A class of tricyclic compounds blocking malaria parasite oocyst development and transmission Antimicrob Agents Chemother 57 425-35

Gamo F J, Sanz L M, Vidal J, de Cozar C, Alvarez E, Lavandera J L, Vanderwall D E, Green D V, Kumar V, Hasan S, Brown J R, Peishoff C E, Cardon L R and Garcia-Bustos J F (2010) Thousands of chemical starting points for antimalarial lead identification Nature 465 305-10

Goodman C D, Su V and McFadden G I (2007) The effects of anti-bacterials on the malaria parasite Plasmodium falciparum Mol Biochem Parasitol 152 181-91

Guiguemde W A, Shelat A A, Bouck D, Duffy S, Crowther G J, Davis P H, Smithson D C, Connelly M, Clark J, Zhu F, Jiménez-Díaz M B, Martinez M S, Wilson E B, Tripathi A K, Gut J, Sharlow E R, Bathurst I, El Mazouni F, Fowble J W, Forquer I, McGinley PL, Castro S, Angulo-Barturen I, Ferrer S, Rosenthal P J, Derisi J L, Sullivan D J, Lazo J S, Roos D S, Riscoe M K, Phillips M A, Rathod P K, Van Voorhis W C, Avery V M and Guy R K (2010) Chemical genetics of Plasmodium falciparum Nature $465311-5$

Hudson A T (1993) Atovaquone - a novel broad-spectrum antiinfective drug Parasitol Today 9 66-8

Johnson D J, Fidock D A, Mungthin M, Lakshmanan V, Sidhu A B, Bray P G and Ward S A (2004) Evidence for a central role for PfCRT in conferring Plasmodium falciparum resistance to diverse antimalarial agents Mol Cell 15 86777

Jortzik E, Zocher K, Isernhagen A, Mailu B M, Rahlfs S, Viola G, Wittlin S, Hunt N H, Ihmels H and Becker K (2015) 
Benzo[b]quinolizinium Derivatives Have a Strong Antimalarial Activity and Inhibit Indoleamine Dioxygenase Antimicrob Agents Chemother 60 115-25

Kelly J X, Smilkstein M J, Brun R, Wittlin S, Cooper R A, Lane K D, Janowsky A, Johnson R A, Dodean R A, Winter R, Hinrichs D J and Riscoe M K (2009) Discovery of dual function acridones as a new antimalarial chemotype Nature 459 270-3

Klayman D L (1985) Qinghaosu (artemisinin): an antimalarial drug from China Science 228 1049-55

Kuhen K L, Chatterjee A K, Rottmann M, Gagaring K, Borboa R, Buenviaje J, Chen Z, Francek C, Wu T, Nagle A, Barnes S W, Plouffe D, Lee M C, Fidock D A, Graumans W, van de Vegte-Bolmer M, van Gemert G J, Wirjanata G, Sebayang B, Marfurt J, Russell B, Suwanarusk R, Price R N, Nosten F, Tungtaeng A, Gettayacamin M, Sattabongkot J, Taylor J, Walker J R, Tully D, Patra K P, Flannery E L, Vinetz J M, Renia L, Sauerwein R W, Winzeler E A, Glynne R J and Diagana T T (2014) KAF156 is an antimalarial clinical candidate with potential for use in prophylaxis, treatment, and prevention of disease transmission Antimicrob Agents Chemother 58 5060-7

Le Manach C, Paquet T, Brunschwig C, Njoroge M, Han Z, Gonzàlez Cabrera D, Bashyam S, Dhinakaran R, Taylor D, Reader J, Botha M, Churchyard A, Lauterbach S, Coetzer T L, Birkholtz L M, Meister S, Winzeler E A, Waterson D, Witty M J, Wittlin S, Jiménez-Díaz M B, Santos Martínez M, Ferrer S, Angulo-Barturen I, Street L $\mathrm{J}$ and Chibale K (2015) A Novel Pyrazolopyridine with in Vivo Activity in Plasmodium berghei- and Plasmodium falciparum-Infected Mouse Models from StructureActivity Relationship Studies around the Core of Recently Identified Antimalarial Imidazopyridazines J Med Chem 12 713-22

Leykauf K, Treeck M, Gilson P R, Nebl T, Braulke T, Cowman A F, Gilberger T W and Crabb B S (2010) Protein kinase a dependent phosphorylation of apical membrane antigen 1 plays an important role in erythrocyte invasion by the malaria parasite PLoS Pathog 6 e1000941

Loria P, Miller S, Foley M and Tilley L (1999) Inhibition of the peroxidative degradation of haem as the basis of action of chloroquine and other quinolineantimalarials Biochem $J$ $339363-70$

Maron M I, Magle C T, Czesny B, Turturice B A, Huang R, Zheng W, Vaidya A B and Williamson K C (2015) Maduramicin rapidly eliminates malaria parasites and potentiates the gametocytocidal activity of the pyrazoleamide, PA21A050. Antimicrob Agents Chemother
AAC.01928-15. [Epub ahead of print]

McNamara C W, Lee M C, Lim C S, Lim S H, Roland J, Nagle A, Simon O, Yeung B K, Chatterjee A K, McCormack S L, Manary M J, Zeeman A M, Dechering K J, Kumar T R, Henrich P P, Gagaring K, Ibanez M, Kato N, Kuhen K L, Fischli C, Rottmann M, Plouffe D M, Bursulaya B, Meister S, Rameh L, Trappe J, Haasen D, Timmerman M, Sauerwein R W, Suwanarusk R, Russell B, Renia L, Nosten F, Tully D C, Kocken C H, Glynne R J, Bodenreider C, Fidock D A, Diagana T T and Winzeler EA(2013) Targeting Plasmodium PI(4)K to eliminate malaria Nature 12 24853

Mueller E A, van Vugt M, Kirch W, Andriano K, Hunt P and de Palacios P I (2006) Efficacy and safety of the six-dose regimen of artemether-lumefantrine for treatment of uncomplicated Plasmodium falciparum malaria in adolescents and adults: a pooled analysis of individual patient data from randomized clinical trials Acta Trop 100 $41-53$

Mzayek F, Deng H, Mather F J, Wasilevich E C, Liu H, Hadi C M, Chansolme D H, Murphy H A, Melek B H, Tenaglia A N, Mushatt D M, Dreisbach A W, Lertora J J and Krogstad D J (2007) Randomized dose-ranging controlled trial of AQ-13, a candidate antimalarial, and chloroquine in healthy volunteers PLoS Clin Trials 2 e6

Nandakumar D N, Nagaraj V A, Vathsala P G, Rangarajan P and Padmanaban G (2006) Curcumin-artemisinin combination therapy for malaria Antimicrob Agents Chemother 50 185960

Phyo A P, Jittamala P, Nosten F H, Pukrittayakamee S, Imwong M, White N J, Duparc S, Macintyre F, Baker M and Möhrle J J (2016) Antimalarial activity of artefenomel (OZ439), a novel synthetic antimalarial endoperoxide, in patients with Plasmodium falciparum and Plasmodium vivax malaria: an open-label phase 2 trial Lancet Infect Dis 16 61-9

Raphemot R, Lafuente-Monasterio M J, Gamo-Benito F J, Clardy J and Derbyshire E R (2015) Discovery of Dual Stage Malaria Inhibitors with New Targets Antimicrob Agents Chemother AAC.02110-15. [Epub ahead of print]

Rastelli G, Antolini L, Benvenuti S and Costantino L (2000) Structural bases for the inhibition of aldose reductase by phenolic compounds Bioorg Med Chem 8 1151-8

Rottmann M, McNamara C, Yeung B K, Lee M C, Zou B, Russell B, Seitz P, Plouffe D M, Dharia N V, Tan J, Cohen S B, Spencer K R, González-Páez G E, Lakshminarayana S B, Goh A, Suwanarusk R, Jegla T, Schmitt E K, Beck H P, Brun R, Nosten F, Renia L, Dartois V, Keller T H, Fidock 
D A, Winzeler EA and Diagana TT (2010) Spiroindolones, a potent compound class for the treatment of malaria Science 329 1175-80

Russo I, Babbitt S, Muralidharan V, Butler T, Oksman A and Goldberg D E (2010) Plasmepsin V licenses Plasmodium proteins for export into the host erythrocyte Nature 463 $632-6$

Soukhathammavong P, Odermatt P, Sayasone S, Vonghachack Y, Vounatsou P, Hatz C, Akkhavong K and Keiser J (2011) Efficacy and safety of mefloquine, artesunate, mefloquineartesunate, tribendimidine, and praziquantel in patients with Opisthorchis viverrini: a randomised, exploratory, open-label, phase 2 trial Lancet Infect Dis 11 110-8

Supan C, Mombo-Ngoma G, Dal-Bianco M P, Ospina Salazar C L, Issifou S, Mazuir F, Filali-Ansary A, Biot C, TerMinassian D, Ramharter M, Kremsner P G and Lell B (2012) Pharmacokinetics of ferroquine, a novel 4aminoquinoline, in asymptomatic carriers of Plasmodium falciparum infections Antimicrob Agents Chemother 56 3165-73

Tham W H, Lim N T, Weiss G E, Lopaticki S, Ansell B R, Bird M, Lucet I, Dorin-Semblat D, Doerig C, Gilson P R, Crabb B S and Cowman AF (2015) Plasmodium falciparum Adhesins Play an Essential Role in Signalling and Activation of Invasion into Human Erythrocytes PLoS Pathog 11 e1005343

Trager W and Jensen J B (1976) Human malaria parasites in continuous culture Science 193 673-5

Trenholme K, Marek L, Duffy S, Pradel G, Fisher G, Hansen F K, Skinner-Adams T S, Butterworth A, Ngwa C J, Moecking J, Goodman C D, McFadden G I, Sumanadasa S D, Fairlie D P, Avery V M, Kurz T and Andrews K T (2014) Lysine acetylation in sexual stage malaria parasites is a target for antimalarial small molecules Antimicrob Agents Chemother 58 3666-78
Vaidya A B, Morrisey J M, Zhang Z, Das S, Daly T M, Otto T D, Spillman N J, Wyvratt M, Siegl P, Marfurt J, Wirjanata G, Sebayang B F, Price R N, Chatterjee A, Nagle A, Stasiak M, Charman S A, Angulo-Barturen I, Ferrer S, Belén Jiménez-Díaz M, Martínez M S, Gamo F J, Avery V M, Ruecker A, Delves M, Kirk K, Berriman M, Kortagere S, Burrows J, Fan E and Bergman L W (2014) Pyrazoleamide compounds are potent antimalarials that target $\mathrm{Na}+$ homeostasis in intraerythrocytic Plasmodium falciparum Nat Commun 25521

Valecha N, Looareesuwan S, Martensson A, Abdulla S M, Krudsood S, Tangpukdee N, Mohanty S, Mishra S K, Tyagi P K, Sharma S K, Moehrle J, Gautam A, Roy A, Paliwal J K, Kothari M, Saha N, Dash A P and Björkman A (2015) Arterolane, a new synthetic trioxolane for treatment of uncomplicated Plasmodium falciparum malaria: a phase II, multicenter, randomized, dose-finding clinical trial Clin Infect Dis $\mathbf{5 1}$ 684-91

Ward P, Equinet L, Packer J and Doerig C (2004) Protein kinases of the human malaria parasite Plasmodium falciparum: the kinome of a divergent eukaryote BMC Genomics 579

Wellems T E (2002) Plasmodium chloroquine resistance and the search for a replacement antimalarial drug Science 298 1246

World Health Organization, World Malaria Report 2015. (http:/ /who.int/malaria/publications/world-malaria-report-2015/ report/en/)

Yeung B K, Zou B, Rottmann M, Lakshminarayana S B, Ang S H, Leong S Y, Tan J, Wong J, Keller-Maerki S, Fischli C, Goh A, Schmitt E K, Krastel P, Francotte E, Kuhen K, Plouffe D, Henson K, Wagner T, Winzeler EA, Petersen F, Brun R, Dartois V, Diagana T T and Keller T H (2010) Spirotetrahydro beta-carbolines (spiroindolones): a new class of potent and orally efficacious compounds for the treatment of malaria J Med Chem 53 5155-64. 


\section{SUPPORTING INFORMATION}

\section{Determination of purity and structural determinations:}

Bruker AC 400 spectrometer was used to record ${ }^{1} \mathrm{H}$ nuclear magnetic resonance $\left({ }^{1} \mathrm{H} \mathrm{NMR}\right)$ and ${ }^{13} \mathrm{C} N \mathrm{NR}$ spectra. Chemical shifts are reported in ( $\mathrm{ppm}$ ) units relative to the internal reference tetramethylsilane (Me4Si). All the exchangeable protons were confirmed by addition of $\mathrm{D}_{2} \mathrm{O}$. Mass spectral data were recorded in APCI-2000. All the compounds were routinely checked by thin-layer chromatography (TLC) and ${ }^{1} \mathrm{H}$ NMR. Aluminum-backed silica gel plates (Merck DC-Alufolien Kieselgel 60 F254) was used for performing the TLC and the spots were visualized by UV light. All solvents were reagent grade and when necessary, were purified and dried by standard methods. Concentration of solutions after reactions and extractions involved the use of a rotary evaporator operating at a reduced pressure. Organic solutions were dried over anhydrous sodium sulfate. Analytical results are within $\pm 0.50 \%$ of the theoretical values. All chemicals were purchased from SigmaAldrich.

Synthesis 2-\{[(4-Chlorophenyl)carbamoyl] amino\} benzamide; RTK-36: Yield: $95 \%$; ${ }^{1} \mathrm{H}$ NMR (DMSO- $d_{6}$ ): 10.6 (br s, 1H, NH), 9.8 (br s, $1 \mathrm{H}, \mathrm{NH}$ ), $8.23(\mathrm{~d}, 1 \mathrm{H}), 7.71(\mathrm{~d}, 1 \mathrm{H}, J=8.27 \mathrm{~Hz}), 7.63(\mathrm{br} \mathrm{s}, 2 \mathrm{H}$, $\left.\mathrm{NH}_{2}\right), 7.53(\mathrm{dd}, 2 \mathrm{H}), 7.42(\mathrm{t}, 1 \mathrm{H}), 7.3(\mathrm{dd}, 2 \mathrm{H}), 7.1(\mathrm{t}$, 1H); ${ }^{13} \mathrm{C}$ NMR (DMSO- $\left.d_{6}\right): 171.96,153.46,140.13$, 138.95, 132.97, 129.53, 129.13, 127.10, 122.73, 121.61, 121.41. $\mathrm{m} / \mathrm{z}=289.9$

2 - [ (Phenylcarbamothioyl)amino] benzamide; RTK-37: Yield: $90 \%$; ${ }^{1} \mathrm{H}$ NMR (DMSO- $d_{6}$ ): 13.1 (br s, 1H, NH), 9.53 (br s, 1H, $\mathrm{NH}), 8.17(\mathrm{~d}, 1 \mathrm{H}), 7.71(\mathrm{t}, 1 \mathrm{H}), 7.47-7.57(\mathrm{~m}, 3 \mathrm{H})$, 7.47 (br s, 2H, $\mathrm{NH}_{2}$ ), 7.35 (t, 1H), 7.28 (dd, 2H), 7.11 $(\mathrm{d}, 1 \mathrm{H}) ; \mathrm{m} / \mathrm{z}=271.31$

2-\{[(3-Chlorophenyl) carbamoyl]amino\} benzamide; RTK-38: Yield: $90 \% ;{ }^{1} \mathrm{H}$ NMR (DMSO- $d_{6}$ ): 10.38 (br s, $\left.1 \mathrm{H}, \mathrm{NH}\right), 9.25$ (br s, $1 \mathrm{H}$, $\mathrm{NH}), 8.17(\mathrm{~d}, 1 \mathrm{H}), 7.77(\mathrm{~d}, 1 \mathrm{H}, J=7.86 \mathrm{~Hz}), 7.67$ (d, 1H), 7.59 (br s, 2H, $\mathrm{NH}_{2}$ ), 7.4-7.48 (m, 2H), 7.31 (t, 1H), 7.13 (d, 1H), 7.03 (s, 1H). m/z = 289.9

\section{2-\{[(3-Methoxyphenyl) carbamoyl $]$ amino $\}$}

benzamide; RTK-39: Yield: $86 \%$; ${ }^{1} \mathrm{H}$ NMR (DMSO- $d_{6}$ ): 10.57 (br s, 1H, NH), 9.70 (br s, 1H, $\mathrm{NH}), 8.25(\mathrm{~d}, 1 \mathrm{H}), 7.73(\mathrm{~d}, 1 \mathrm{H}, J=8.23 \mathrm{~Hz}), 7.64$ (br $\left.\mathrm{s}, 2 \mathrm{H}, \mathrm{NH}_{2}\right), 7.45(\mathrm{t}, 1 \mathrm{H}), 7.24(\mathrm{~s}, 1 \mathrm{H}), 7.06(\mathrm{~d}, 1 \mathrm{H})$, 7.02-7.11 (m, 2H), $6.55(\mathrm{~d}, 1 \mathrm{H}), 3.74(\mathrm{~s}, 3 \mathrm{H}) . \mathrm{m} / \mathrm{z}=$ 285.9

2-\{[(2-Chlorophenyl)carbamothioyl] amino\}benzamide; RTK-41: Yield: $88 \% ;{ }^{1} \mathrm{H}$ NMR (DMSO- $d_{6}$ ): 11.20 (br s, $1 \mathrm{H}, \mathrm{NH}$ ), 10.25 (br s, $1 \mathrm{H}$, $\mathrm{NH}), 8.48(\mathrm{~d}, 1 \mathrm{H}), 7.98(\mathrm{~d}, 1 \mathrm{H}, J=7.32 \mathrm{~Hz}), 7.81(\mathrm{t}$, $1 \mathrm{H}), 7.69\left(\mathrm{br} \mathrm{s}, 2 \mathrm{H}, \mathrm{NH}_{2}\right), 7.65(\mathrm{~d}, 1 \mathrm{H}), 7.53(\mathrm{~d}, 1 \mathrm{H})$, 7.32-7.51 (m, 2H), $7.15(\mathrm{t}, 1 \mathrm{H}) . \mathrm{m} / \mathrm{z}=305.9$

2-\{[(2-Fluorophenyl)carbamothioyl]amino\} benzamide; RTK-42: Yield: $88 \%$; ${ }^{1} \mathrm{H}$ NMR (DMSO- $d_{6}$ ): 11.28 (br s, $\left.1 \mathrm{H}, \mathrm{NH}\right), 10.21$ (br s, $1 \mathrm{H}$, $\mathrm{NH}), 8.46(\mathrm{~d}, 1 \mathrm{H}), 7.97(\mathrm{~d}, 1 \mathrm{H}, J=8.71 \mathrm{~Hz}), 7.82(\mathrm{t}$, 1H), 7.71 (br s, 2H, $\left.\mathrm{NH}_{2}\right), 7.65(\mathrm{~d}, 1 \mathrm{H}), 7.51(\mathrm{~d}, 1 \mathrm{H})$, 7.43-7.49 (m, 2H), 7.14 (t, 1H). $\mathrm{m} / \mathrm{z}=289.9$

2-\{[(4-Bromophenyl)carbamoyl]amino $\}$ benzamide; RTK-43: Yield: $93 \%$; ${ }^{1} \mathrm{H}$ NMR (DMSO- $d_{6}$ ): 10.62 (br s, 1H, NH), 9.83 (br s, $1 \mathrm{H}$, $\mathrm{NH}), 8.25(\mathrm{~d}, 1 \mathrm{H}), 7.70(\mathrm{~d}, 1 \mathrm{H}, J=8.03 \mathrm{~Hz}), 7.64(\mathrm{br}$ s, $\left.2 \mathrm{H}, \mathrm{NH}_{2}\right), 7.48(\mathrm{dd}, 2 \mathrm{H}), 7.45(\mathrm{dd}, 2 \mathrm{H}), 7.42(\mathrm{t}$, $1 \mathrm{H}), 7.01(\mathrm{t}, 1 \mathrm{H}) . \mathrm{m} / \mathrm{z}=335.9$

2-(\{[4-(Methylthio)phenyl]carbamoyl $\}$ amino) benzamide; RTK-44: Yield: $95 \% ;{ }^{1} \mathrm{H}$ NMR (DMSO- $d_{6}$ ): 10.58 (br s, 1H, NH), 9.69 (br s, 1H, $\mathrm{NH}), 8.25(\mathrm{~d}, 1 \mathrm{H}), 7.70(\mathrm{~d}, 1 \mathrm{H}, J=7.13 \mathrm{~Hz}), 7.62(\mathrm{br}$ s, $\left.2 \mathrm{H}, \mathrm{NH}_{2}\right), 7.48(\mathrm{dd}, 2 \mathrm{H}), 7.43(\mathrm{t}, 1 \mathrm{H}), 7.20(\mathrm{dd}$, $2 \mathrm{H}), 7.01(\mathrm{t}, 1 \mathrm{H}), 2.43(\mathrm{~s}, 3 \mathrm{H}) . \mathrm{m} / \mathrm{z}=301.9$

2-\{[(4-Fluorophenyl)carbamoyl]amino $\}$ benzamide; RTK-45: Yield: $94 \% ;{ }^{1} \mathrm{H}$ NMR (DMSO- $d_{6}$ ): 10.60 (br s, 1H, NH), 9.70 (br s, $1 \mathrm{H}$, $\mathrm{NH}), 8.23(\mathrm{~d}, 1 \mathrm{H}), 7.69(\mathrm{~d}, 1 \mathrm{H}, J=8.23 \mathrm{~Hz}), 7.63(\mathrm{br}$ $\left.\mathrm{s}, 2 \mathrm{H}, \mathrm{NH}_{2}\right), 7.5(\mathrm{dd}, 2 \mathrm{H}), 7.43(\mathrm{t}, 1 \mathrm{H}), 7.10(\mathrm{dd}, 2 \mathrm{H})$, $7.0(\mathrm{t}, 1 \mathrm{H}) . \mathrm{m} / \mathrm{z}=273.9$

2-(\{[4-Chloro-3-(trifluoromethyl)phenyl] carbamoyl\} amino) benzamide; RTK-46: Yield: 86\%; ${ }^{1} \mathrm{H}$ NMR (DMSO- $d_{6}$ ): 10.85 (br s, $1 \mathrm{H}, \mathrm{NH}$ ), 10.18 (br s, 1H, NH), 8.26 (d, 1H), 8.11 (s, 1H), 7.74 (dd, 2H), 7.68 (br s, 2H, NH $), 7.60(\mathrm{~d}, 1 \mathrm{H}, J=8.56$ $\mathrm{Hz}), 7.44(\mathrm{t}, 1 \mathrm{H}), 7.04(\mathrm{t}, 1 \mathrm{H}) . \mathrm{m} / \mathrm{z}=357.9$

2-(\{[4-(Trifluoromethyl)phenyl]carbamoyl $\}$ amino)benzamide; RTK-47: Yield: 91\%; ${ }^{1} \mathrm{H}$ NMR 
(DMSO- $d_{6}$ ): 13.14 (br s, 1H, NH), 10.18 (br s, 1H, $\mathrm{NH}), 7.95(\mathrm{~d}, 1 \mathrm{H}), 7.81(\mathrm{~d}, 1 \mathrm{H}, J=8.78 \mathrm{~Hz}), 7.77$ (br $\left.\mathrm{s}, 2 \mathrm{H}, \mathrm{NH}_{2}\right), 7.71(\mathrm{t}, 1 \mathrm{H}), 7.63(\mathrm{dd}, 2 \mathrm{H}), 7.45(\mathrm{dd}$, $2 \mathrm{H}), 7.36(\mathrm{t}, 1 \mathrm{H}) . \mathrm{m} / \mathrm{z}=322.9$

2-\{[(4-Bromophenyl)carbamothioyl]amino\} benzamide; RTK-48: Yield: 89\%; ${ }^{1} \mathrm{H}$ NMR (DMSO- $d_{6}$ ): 13.06 (br s, 1H, NH), 9.71 (br s, 1H, $\mathrm{NH}), 7.95$ (d, 1H), 7.78 (t, 1H), 7.67 (br s, 2H, $\mathrm{NH}_{2}$ ), $7.5(\mathrm{~d}, 1 \mathrm{H}, J=7.99 \mathrm{~Hz}), 7.45(\mathrm{dd}, 2 \mathrm{H}), 7.34(\mathrm{t}, 1 \mathrm{H})$, 7.27 (dd, $2 \mathrm{H}) . \mathrm{m} / \mathrm{z}=350.23$

2-\{[(4-Fluorophenyl)carbamothioyl]amino\} benzamide; RTK-49: Yield: 81\%; ${ }^{1} \mathrm{H}$ NMR (DMSO- $d_{6}$ ): 13.01 (br s, 1H, NH), 9.68 (br s, 1H, $\mathrm{NH}), 7.94(\mathrm{~d}, 1 \mathrm{H}), 7.68$ (br s, 2H, $\mathrm{NH}_{2}$ ), 7.51 (dd, $2 \mathrm{H}), 7.39(\mathrm{t}, 1 \mathrm{H}), 7.33(\mathrm{~d}, 1 \mathrm{H}, J=8.91 \mathrm{~Hz}), 6.66(\mathrm{dd}$, $2 \mathrm{H}), 6.46(\mathrm{t}, 1 \mathrm{H}) . \mathrm{m} / \mathrm{z}=289.32$

2-\{[(4-Chlorophenyl)carbamothioyl]amino\} benzamide; RTK-50: Yield: 92\%; ${ }^{1} \mathrm{H}$ NMR (DMSO- $d_{6}$ ): 13.02 (br s, 1H, NH), 9.67 (br s, 1H, $\mathrm{NH}), 7.94(\mathrm{~d}, 1 \mathrm{H}), 7.77$ (t, 1H), 7.64 (br s, 2H, $\mathrm{NH}_{2}$ ), $7.53(\mathrm{dd}, 2 \mathrm{H}), 7.46(\mathrm{~d}, 1 \mathrm{H}, J=7.91 \mathrm{~Hz}), 7.44(\mathrm{t}, 1 \mathrm{H})$, $7.33(\mathrm{dd}, 2 \mathrm{H}) . \mathrm{m} / \mathrm{z}=305$

\section{Supplementary Figure 1}

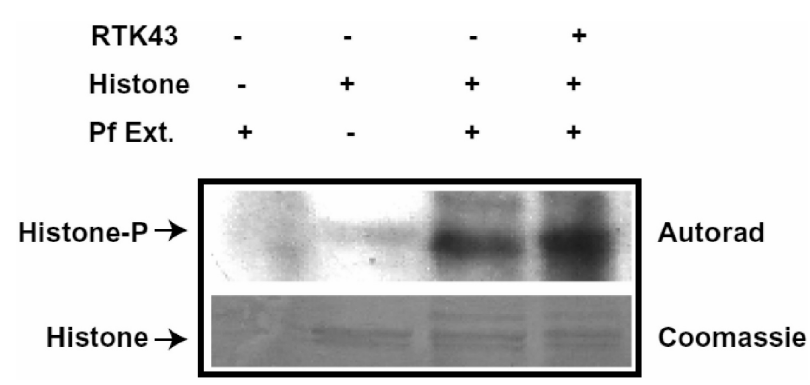

Supplementary Figure 1. Effect of RTK43 on in vitro kinase assay of $P$. falciparum extract. In vitro kinase assay was performed by adding $P$. falciparum extract to a reaction mixture containing radioactive $\left[\gamma-{ }^{32} P\right] A T P$ and $3 \mu \mathrm{g}$ histone $\mathrm{H1}$ as substrate. The presence or absence of the Drug, $P$. falciparum extract and histone in each lane is indicated on the top. The reaction mixtures were resolved in SDS-PAGE followed by autoradiography. The top panel shows the phosphorylated histone (Histone-P) and the bottom panel shows the coomassie stained gel.

\section{Materials and methods}

Kinase assay. Fresh or frozen parasite pellets were lysed in 10 volume of ice cold buffer containing $50 \mathrm{mM}$ $\beta$-glycerol phosphate (pH-7.3), $1 \%$ Triton $\mathrm{X}-100$ and $1 \mathrm{mM}$ DTT in the presence of complete protease and phosphatase inhibitor cocktail (Sigma) and incubated on rotating wheel overnight at $4^{\circ} \mathrm{C}$. Parasite lysate was cleared by centrifugation at $15000 \mathrm{xg}$ for 15 minutes at $4^{\circ} \mathrm{C}$. The kinase reactions were performed as per the protocol described elsewhere (Leykauf et al., 2010) with appropriate modifications. Typically, kinase reaction was performed with $15 \mu$ g of Pf extract in standard kinase buffer containing $20 \mathrm{mM}$ Tris-Cl

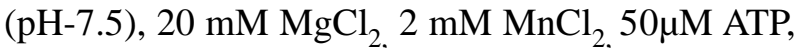
$10 \mu \mathrm{Ci}\left[\gamma{ }^{32} \mathrm{P}\right] \mathrm{ATP}$ and $3 \mu \mathrm{g}$ of Histone $\mathrm{H} 1$. After 30 minutes of incubation at $30^{\circ} \mathrm{C}$, the reaction was stopped by addition of 2 XSDS loading buffer. Finally, the reaction products were resolved in $12 \%$ SDSpolyacrylamide gel. The gel was further dried and exposed for auto radiography following commassie blue staining. 